\title{
Looking at the Community of Human Destiny from Chinese Wisdom
}

\author{
Jianwei Jian \\ Ideological and Political Theory Course Teaching Department \\ Shaanxi Fashion Engineering University \\ Xi'an, China
}

\begin{abstract}
The Community of Human Destiny, which has been proposed by General Secretary Xi Jinping for five years, has reached an international consensus and has become a unique Chinese wisdom in global governance. The Community of Human Destiny develops the core value concept and fine tradition of excellent traditional culture, but also the inheritance and development of Marx's "community" ideology, indicates the ultimate goal and development direction of human society and its realistic path, and has a great significance to build a new type of new international political order and China's diplomacy.
\end{abstract}

Keywords-Chinese wisdom; traditional culture core; community of human destiny

\section{INTRODUCTION}

The report of the 19th National Congress pointed out: We must build a "lasting peace, universal security, common prosperity, openness and inclusiveness, and a clean and beautiful world." This is a vivid interpretation of the general connotation of the Community of Human Destiny by General Secretary Xi Jinping, including the economic outlook with mutual benefits and win-win results, the outlook of security in fairness and justice, the inclusive and innovative development, the ethical outlook of Confucian wisdom, and the outlook of ecological civilization. In 2013, General Secretary Xi Jinping first expounded the concept of the Community of Human Destiny in his speech at the Moscow Institute of International Relations, which is a powerful response to the "question of the world". The Community of Human Destiny has been proposed for five years now and has become a global consensus. Not only was it written in the party constitution and written into the constitutional preamble after the 19th National Congress of the People's Republic of China, but it has also been written into the UN resolution, Security Council resolutions and the UN Human Rights resolutions beyond national borders. It will be a resolution with unique Chinese wisdom in global governance. The Community of Human Destiny is based on the historical basis of "the transformation of history into world history", the product of the Chinese tradition of "harmonious" culture and the exchange of civilizations in various countries in the West. Its common goal is to seek benefits for humanity, seek common ground for the world, and build new order of globalization, the improvement of global governance, and the realization of human beings as a "real community" of "class existence."

\section{HARMONY: CULTURAL PURPORT OF THE COMMUNITY OF HUMAN DESTINY}

The Chinese civilization, bred by a long history of more than 5,000 years, has been adhering to the national spirit of "loving peace, good neighborliness and friendship, and harmony and unity". "Harmony" is the essence of Chinese culture. "Harmony" has multiple connotations in the traditional Chinese culture, and it is first embodied in the harmony between man and nature. "Yi Zhuan," records: "There is heaven and earth, and then everything." Heaven and earth refer to the entirely natural world, is the organic unity of the source of all things, "and heaven and earth and its virtue" reflect the harmony between man and nature. In "The Doctrine of the Mean", it is stated in the book: "Like the cultivation of the heaven and the earth, you can consult with the heavens and the earth," and "the reference to the heaven and the earth" refers to the harmony of heaven and man. After the Han and Song dynasties, the harmonious doctrine of heaven and man gradually evolved into the concept of "Harmony between man and nature". Although most of the studies of ancient Chinese thinkers point to the important proposition that "Harmony between man and nature", the debate on the relationship between man and nature in the theoretical circle has never stopped and formed a number of schools. It is worth mentioning that the concept of "Harmony between man and nature" is the core of the study of ancient Chinese thinkers, and is the value orientation pursued by the three mainstream schools of Confucianism, Taoism and Buddhism.

One of the highest realms of harmony is the realization of the "Great Harmony Society", which is the social ideal of the Chinese nation over the past several years. It can be traced back to the term "making all nations live together peacefully" (from the "Shang Shu•Yi Dian" It means adjusting the relations among various vassal states, making the world harmonious. Kang Youwei wrote in his book: "The world of great harmony, the world is the public, there is no class, everything is equal", and it also advocates that class and private ownership should be abolished. Human beings can only achieve equality in the world by maintaining equality. Sun Yat-sen and others later spread the idea of "compassing the world". Since the founding of New China, several generations of leaders of the country have upheld and practiced the diplomatic concept of peace, advocated no alliance, no confrontation, practiced the power of peaceful diplomacy against the power of hegemonist power, 
and promoted the realization of the ideal world in great harmony.

In his speech in memory of the 50th anniversary of the establishment of diplomatic relations between China and France in 2014, Xi Jinping pointed out: "sharing the peaceful world and the world of great harmony is the ideal of the Chinese nation for thousands of years." It Reflects the Chinese people's pursuit of peace in the worldwide pattern, fits together with Marx's commitment to the universal dimension of achieving communist ideals. From the ancient idea of "Harmony between man and nature" to the Five Principles of Peaceful Coexistence established in the early days of the founding of New China, to the time outlook of peace and development, and to the new security concept of mutual trust, mutual benefit, and equal cooperation, from building a harmonious society, world to the human destiny community, the Chinese nation has always been committed to the realization of the ideals of world peace, universal harmony.

In today's world, various uncertainties have increased significantly. Humankind is facing problems such as ecological crisis, fiscal deficit, poverty, racial conflicts, and energy resource imbalances. Countries are becoming closer and closer each other under the influence of the Internet and information technology, whether it is Western "neo-liberalism" or the "Washington consensus" advocated by privatization, liberalization, and stabilization, it has been difficult to solve this complex and huge series of social problems. The traditional Chinese "harmony" culture is human survival and development provide a way out. To promote the harmonious coexistence of different civilizations in the world with the Chinese "Harmony" culture, we can improve the global governance system and contribute to China's wisdom and China's programs in order to get out of the global governance plight.

The concept of human destiny community is not only a summary of the core value concept of the excellent Chinese traditional culture, but also the inheritance and sublimation of Marx's doctrines such as the "community" and the "nature of human". The essence of the latter is the realization of human freedom. The development and its human liberation, namely unity. The Chinese Communist Party has taken the courage to stand at the forefront and stands at the height of the times, creatively realizing Marxism localized in China with great political courage, and finding an important magic weapon for solving global problems.

The Community of Human Destiny is based on the foundation of the whole humanity's destiny and transcends national boundaries. It not only satisfies national interests, but also takes into consideration the legitimate concerns of other countries. From a domestic point of view, a perfect society in which people should pursue harmony at the three levels of interpersonal, social, and 56 nationalities; from a global perspective, which needs the exchange and recognition of heterogeneous civilizations in different countries and negating the theory of a single civilization, ultimately achieving the external unity of a pluralistic civilization.

\section{ChINESE DREAM: PRACTICE REGULATION OF THE COMMUNITY OF HUMAN DESTINY}

In 2012, when General Secretary Xi Jinping visited the "Road to Revival" exhibition, he put forward the "Chinese Dream" for the first time. The "Chinese Dream" profoundly reveals the main theme line of historical development in modern China. It profoundly depicts the history of the Chinese nation since its modernization, continuous exploration, and unremitting struggle, witnessing the Chinese nation's rise from standing up to becoming rich and strong. This great transformation reflects the extraordinary history of the Chinese nation. The "Chinese Dream" sprouted at the time of the nation's peril, and later found its hope under the leadership of the Chinese Communist Party. Through the passage of generations, it became the most popular expression of the governance of the Chinese communists, and it has important guiding significance for the Chinese revolution, construction, reform, and development.

The "Chinese Dream" has rich connotations and extensions. From a personal perspective, the Chinese dream is the Chinese people's dream of pursuing happiness, the dream of the young generation, and the dream of the Chinese people from generation to generation. From a national perspective, the Chinese dream is that the country flourishes and people live in peace; the country's prosperous dream is a dream rooted in the hearts of the people. It is the dream of the Chinese nation's sons and daughters living in harmony both at home and abroad. It is the dream of the great rejuvenation of the Chinese nation. From an extensional perspective, the Chinese dream is not only a national dream, but also a personal dream, and it is also a dream of world development in pursuit of peace.

In 2008,the theme of the "one world, one dream" of the Beijing Olympic Games proclaimed to the world the relationship between the Chinese Dream and the world's dreams, mutual solidarity and interconnection. The Chinese Dream belongs not only to China but also to the world. On October 22, 2015, Xi Jinping pointed out in his speech at the City of London: "... China's development will surely be in the midst of world development, and it will inject more vitality and bring more opportunities to the common development of all countries in the world." Reflecting the principle of dialectic relationship between the part and the whole, on the one hand, the overall decision part, China's development can not be separated from the world, the world's development provides opportunities for China; on the other hand, part of the overall impact, China has become the world's second largest economy, becoming a pull The important engine of the world economy has become more and more influential in the international arena. The development of the world needs the support of China.

The Chinese Dream not only painted the blueprint for the ideal, but also provided a concrete path for its realization. The roads of China, the spirit of China, and the power of China are key words for realizing the Chinese dream, but the realization of the Chinese dream needs more guarantees. General Secretary Xi Jinping pointed out: "Today we are closer to the goal of great rejuvenation than any other time in history. We are more confident and capable of achieving this goal than at 
any time in history. At the same time, China is still and will remain in the primary stage of socialism for a long time. The basic national conditions have not changed..." To realize the Chinese dream, it is also necessary to establish China's selfconfidence and consistently adhere to the ideological line of seeking truth from facts and the fine tradition of hard work and struggle. "The Chinese dream can be achieved without knocking on drums and drums." This shows that the Chinese dream is facing severe challenges, namely, how to ensure sustained and healthy economic development, how to ensure social harmony and stability, how to ensure the ecological environment, and how to solve corruption problems within the party. How to create a peaceful international environment, etc. The realization of the Chinese dream in the new era will be devoted to a great revolution, great struggle, and great cause.

\section{ONE BELT AND ONE ROAD: REALISTIC CHOICES OF THE COMMUNITY OF HUMAN DESTINY}

The "One Belt and One Road" is a mutually beneficial and win-win opening strategy based on the valuable experience and revelations left over from the ancient Silk Road put forward by Chinese President Xi Jinping in 2013. So far, it has become the world's most popular international public goods, attracting the active participation of many countries in Asia, Europe, and Africa in terms of transportation infrastructure, trade and investment, energy cooperation, and regional integration, not only leading the way. The new journey of China's opening to the outside world has also injected a vitality into the development of the world economy. Countries around the world are ushering in a new era of joint construction and sharing. Different from the "New Silk Road" strategy proposed by the United States, the purpose of the "One Belt and One Road" is mainly to help developing countries and underdeveloped countries along the Belt and Road to achieve industrialization and informatization of infrastructure, and to pass policies, funds, and trade between countries.

The "One Belt and One Road" is a major strategy proposed by China in the light of both domestic and international economic and political backgrounds. It is also a concrete measure for China to carry out multilateral diplomacy. China has always advocated and adhered to the development concept of "going alone, going all the way" and the concept of righteousness and benefit. China has not only developed itself through the "Belt and Road Initiative," but more importantly, it has driven countries along the route to mutual benefit. In this sense, the "One Belt and One Road" is the realistic choice of the Community of Human Destiny.

The world today is undergoing major changes and major adjustments. With the continuous deepening of the international division of labor, the accelerating pace of technological innovation, and the ever-increasing degree of informatization, the tide of economic globalization is irreversible, and the trend of super globalization is approaching. At the same time, the voices that have questioned globalization have come and gone, and skeptics generally believe that the global problems faced by humanity in today's world, such as economic crisis, environmental crisis, poverty crisis, regional conflicts, and fiscal deficits, are ultimately caused by globalization. Anti-globalization or anti-globalization waves swept. Many global issues that plagued mankind are not caused by economic globalization, but are caused by wars, regional conflicts, racial disputes, etc. The solution to this series of problems is to seek peace, promote reconciliation, and restore stability, so as to make the economy more dynamic, more inclusive and sustainable.

In today's world, people are living in an era of economic globalization where both pros and cons coexist and interweave. On the one hand, economic globalization has promoted the rapid economic growth of all countries in the world, promoted the effective allocation and flow of resource elements on a global scale, and had a positive impact on all participating countries in the world. Furthermore, with the economic globalization, not only the establishment of a modern market system, but also the imbalance of the international political order, the unification of the cultural form, manifested itself as the Western world's leading "egoist" value appeal to lead globalization. The community of human destiny is a program to consolidate China's wisdom to improve the global governance system. It is conducive to evading the "Thucydides trap" and promoting the collapse of the old system of global governance and the establishment of a new order.

\section{CONCLUSION}

Under the new circumstances of globalization, China has clearly defined its role and status in the process of economic globalization and advocated the construction and development of a development-oriented globalization. Through successive G20 summits, BRICS summits, the One Belt One Road International Cooperation Summit, the Global Political Summit, and the Boao Forum for Asia BFA), China is taking a positive attitude, an open and inclusive mindset, and through comprehensive expansion of opening up, holding high the banner of multilateralism and promoting multilateralism. , bilateral trade cooperation; through dialogues, establish cooperation mechanisms to promote innovation, vitality, linkage, and inclusive growth in the world economy; talking about the road to cooperation and governance, and realize the mutual learning and mutual benefit of the countries.

\section{REFERENCES}

[1] The Top Ten Academic Hot Spots in China in 2017 [J]. Academic Monthly, 2018, 50(01): 5-10.

[2] Li Xuelin. Philosophical Implications of Human Destiny Community[J].Yunnan Social Sciences,2018(01):14-19.

[3] People's Forum "Special Planning" Group. Xi Jinping's Human Destiny Community Thought [J]. People's Forum, 2017(28).

[4] Wang Yibiao. The Atmosphere of Xi Jinping's Human Destiny Community[J]. People's Forum, 2017(28).

[5] Xi Jinping talks about governance and governance of the country's second volume, Foreign Languages Press, November 2017. 